\title{
交差点での右左折における目標操舵角生成手法
}

川勝 俊輝 ${ }^{* 1}$, 毛利 宏*2

\section{A study on steering angle control method under right/left cornering in an intersection}

\author{
Toshiki KAWAKATSU*1 and Hiroshi MOURI ${ }^{* 2}$ \\ ${ }^{* 1, * 2}$ Tokyo University of Agriculture and Technology \\ 2-24-16 Naka-cho, Koganei-shi, Tokyo 184-8588, Japan
}

\begin{abstract}
Many articles have reported that the white lines painted on both sides of highways are used by automatically driven vehicles to control their lateral movement when driving. They are detected by stereo cameras or radars. And GPS is used as an additional information for improving its robustness and reliability. However, when we think about an urban area, the stereo cameras and radars cannot recognize any white lines because white lines do not exist at intersection. Therefore, a method for controlling a vehicle without environmental recognition becomes necessary. In our method, the steering angle is controlled by using simple map information comprising nodes and links of roads, which are widely used in navigation systems, and the data of the vehicle's position, which is obtained continuously. In addition, by using two front gaze points to solve the problem associated with one front gaze point, we propose a method that allows a vehicle to steer smoothly when turning at intersection. We performed an experiment using an actual vehicle under the same conditions as those used in the simulation. The results confirmed the validity of our proposed method because the target steering angles at each corner and the driving trajectory of the actual vehicle were almost the same as those obtained using the simulation.
\end{abstract}

Received: 6 March 2017; Revised: 18 April 2017; Accepted: 7 June 2017

Keywords : Autonomous driving, GPS, Map information, Clothoid curve, Automatic steering control

\section{1. 緒言}

高速道路における自動運転技術には車両の横制御として白線認識によるものが多く報告されている(魚住，菅沼， 2011)(Mouri et al., 2002)。これは，車両に搭載したステレオカメラやレーザレーダを用いて白線を認識し，車線を 逸脱しないように走行コースを維持する技術である. ステレオカメラは，二つのカメラの映像の視差を使つて距 離の検出を行うものであり，レーザレーダは，レーザパルスを照射し，反射されたパルスを検出するまでの時間 により距離計測を行うものである.高速道路は遠方まで視界が確保され, さらに操舵量が少ないといった点から, 白線認識に適した環境と言える.

一方で市街地を想定した場合，路肩での駐車車両や車間距離の短い他の車両，右左折時の大きな曲率によりス テレオカメラやレーザレーダでは白線が認識できない等の課題がある.特に, 交差点では白線が存在しないため, 上記の環境認識に依らない制御手法も必要となる.

従来の走行経路の生成手法としては，直線と円弧を接続して経路を生成するもの(磯谷他，2011)があるが，これ は直線と円弧の境界で曲率がステップ状に変化してしまうため，操舵角速度が急激に変化するという問題点があ る(菅沼，松井，2011). 横方向の乗り心地はジャーク（横加加速度）によると言われているため，乗り心地向上の ためには操舵角速度を小さく抑えることが有効である。そのためには，曲率の二階微分までの連続性を保証する

No.17-00099 [DOI:10.1299/transjsme.17-00099], J-STAGE Advance Publication date : 22 June, 2017

本論文は，第25回交通・物流部門大会 講演論文集(2016), No.1131の掲載内容に基づいた論文である.

*1 学生員, 東京農工大学 工学府（干184-8588 東京都小金井市中町 2-24-16）

*2 正員, 東京農工大学 工学府

E-mail of corresponding author: s162743z@st.go.tuat.ac.jp 
必要がある，そこで，本手法では曲率の二階微分までの連続性を保証することでドライバの乗り心地を考慮した 経路を生成し，その経路を追従するような目標操舵角を生成する.

目標経路追従手法として, 磯谷らは目標経路の曲率と車速から算出される目標ヨーレイトを実現するフィード フォワード制御器によって操舵角制御を行っている(磯谷他, 2011)が，これは万が一目標経路から外れた場合に は復帰できないという課題もある．また，荻原らは一般的な前方注視モデルを用いて，目標軌道と一つの前方注 視点との偏差に応じて操舵角を算出している(荻原他, 2015). しかし前方注視点が一点の場合, 右左折においてコ 一ナ初期に操舵角, 操舵角速度が共に大きく発生し, 曲率の大きな目標経路に対してオーバーシュートやショー トカットすることなく滑らかに走行することは難しい.

そこで, 前方注視点を二点設けることで前述の問題を解決し, 交差点での右左折をより滑らかに走行する手法 を提案する. また，ナビゲーション等で広く用いられている道路のノードとリンクで構成される直線的な簡易地 図情報と時々刻々と得られる自車の位置・姿勢情報を利用し，自車の位置・姿勢に応じて操舵角を制御する.

本稿では，シミュレーションと実車実験によって車両の走行軌跡と操舵角のデータから提案手法の有効性を検 証する，なお，本稿における「滑らかな操舵」とは「走行軌跡がクロソイド曲線に近くなる操舵」と定義する. クロソイド曲線は緩和曲線の一種であり, 道路の直線からカーブにかけて曲率が一定の変化率で変化するため, 一定車速ならば，一定操舵角速度で走行できる経路となっている.

\section{2. 目標操舵角生成手法}

本手法では，目標操舵角を生成するために走行経路がクロソイド曲線となる目標ヨーレイトを決定する必要が ある，そのための設計パラメータは，走行経路と道路の位置関係から決定される．以下には，それぞれの手順の 詳細について順を追って示寸.

\section{$2 \cdot 1$ 目標ヨーレイトの決定方法}

クロソイド曲線とは, 曲率が一定の変化率で変化する緩和曲線をさすが, 本稿では曲率が一定の変化率で変化 寸る部分と一定の部分を組み合わせて曲線部を構成する。このとき, 90 度の左折を行う場合のクロソイド曲線の 経路例を図 1 の左図に，そのときの曲率 $\rho$ を破線で図 1 の右図にそれぞれ示す.
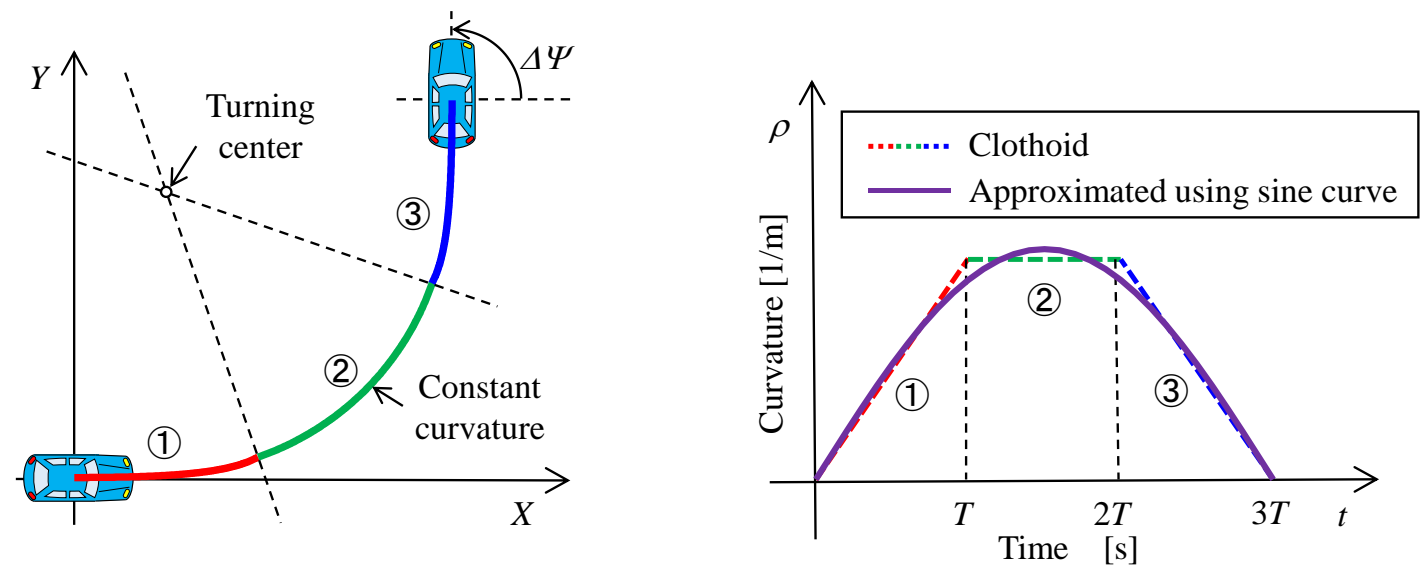

Fig. 1 A clothoid curve is a type of transition curve, and it is applied to the road's configuration of highways. Clothiod curves have three section: one where the curvature is increasing (section 1), one where the curvature is constant (section 2) and one where the curvature is decreasing (section 3). The time spent in each section is $T$, and these are shown in figure 1. Clothiod curve has discontinuities at the border of the three sections; in addition, it is difficult to handle. From this reason, the curvature of the clothoid curve is approximated using a sine curve to ensure its continuity. 
ただし，図 1 の右図において，曲率 $\rho$ が増大する区間（区間(1) : 赤線），一定の区間（区間(2)：緑線），減少す る区間（区間(3)：青線）の時間は等しく $T[\mathrm{~s}]$ とした.これはコーナの進入時と脱出時の操舵角速度を均等に，か つ小さくするためである.

図 1 の右図から分かるように，クロソイド曲線の曲率は区間の境目で不連続が生じ，一階微分が定義できない ため扱いが難しい，そこで，本稿ではクロソイド曲線の曲率を sin 関数で近似する．これにより，曲率の二階微 分までの連続性が保証される，近似した曲率を図 1 の右図に紫色実線で示す．また，クロソイド曲線上を走行中 の車速 $V$ は一定とすると，車両のヨーレイト $\gamma$ は曲率 $\rho$ を用いて $\gamma=\rho V$ という式で表される．以下に $\sin$ 関数で 近似した車両の目標ヨーレイトの算出方法を示寸.

図 1 の右図より, $\sin$ 関数で近似したヨーレイトの半周期は $3 T$ となるので, 車両の目標ヨーレイト $\gamma^{*}$ は振幅 $A$ を用いて式（1）で表される.

$$
\gamma *(t)=A \sin \left(\frac{\pi}{3 T} t\right)
$$

ここで, 図 1 の左図に示すようにクロソイド曲線上を走行する際の車両のヨー角変化量を $\Delta \Psi$ とすると, 車両 のヨーレイトを時間 0[sec]から $3 T$ [sec]まで積分した值となるので, 振幅 $A$ は式（2）のように決定される.

$$
\Delta \Psi=\int_{0}^{3 T} A \sin \left(\frac{\pi}{3 T} t\right) d t \quad \therefore A=\frac{\pi}{6 T} \Delta \Psi
$$

式（1），(2）からクロソイド曲線上を走行する際の車両の目標ヨーレイトは式（3）で表せる.

$$
\gamma^{*}(t)=\frac{\pi}{6 T} \Delta \Psi \sin \left(\frac{\pi}{3 T} t\right)
$$

上式において， $\Delta \Psi$ は道路形状で決まる定数であるので, 目標ヨーレイトの決定に必要な設計パラメータは時 間 $T$ のみである.

\section{$2 \cdot 2$ 時間 $T_{o p t}$ の決定方法}

時間 $T$ によって, 走行経路が変わる様子を図 2 に示寸. 図 2 より, 時間 $T$ を大きく寸ると経路が緑線, 赤線, 青線へと変わることが確認できる，このうち，目標となるリンクに追従する経路は赤線であり，このときの時間 $T$ を $T_{\text {opt }}$ と呼ぶことにする. 以下に, $T_{o p t}$ の決定方法を示す.

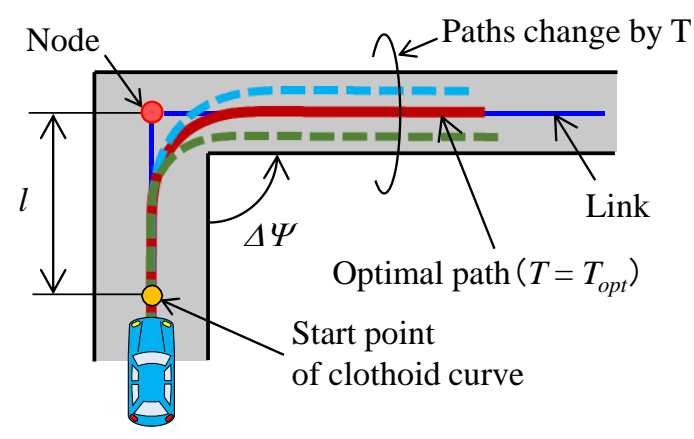

Fig. 2 Figure 2 shows the vehicle trajectory depends on $T$. The path changes from green to red and eventually to a blue line as the $T$ increases; if the $T$ is too low, the vehicle turns too early, and if it is too high, the vehicle turns too late. The $T$ required to follow the target link is $T_{\text {opt }} . l$ is the distance from the start point of the clothoid curve to the next target node. 
図 2 に示すようにクロソイド曲線が始まる点と次に目指すノードまでの距離を $l$ とすると, 時間 $T_{\text {opt }}$ と距離 $l$ は 図 3 の左図に示すように線形な関係があることが分かった。 なお，図 3 の左図は 90 度のコーナを走行する場合 $(\Delta \Psi=\pi / 2)$ の $T_{\text {opt }}$ を示す. 図中の式の係数 $T_{\text {gain }}$ はグラフの傾きを示しており, 車速に依らずコーナの角度によ って決まる定数である.
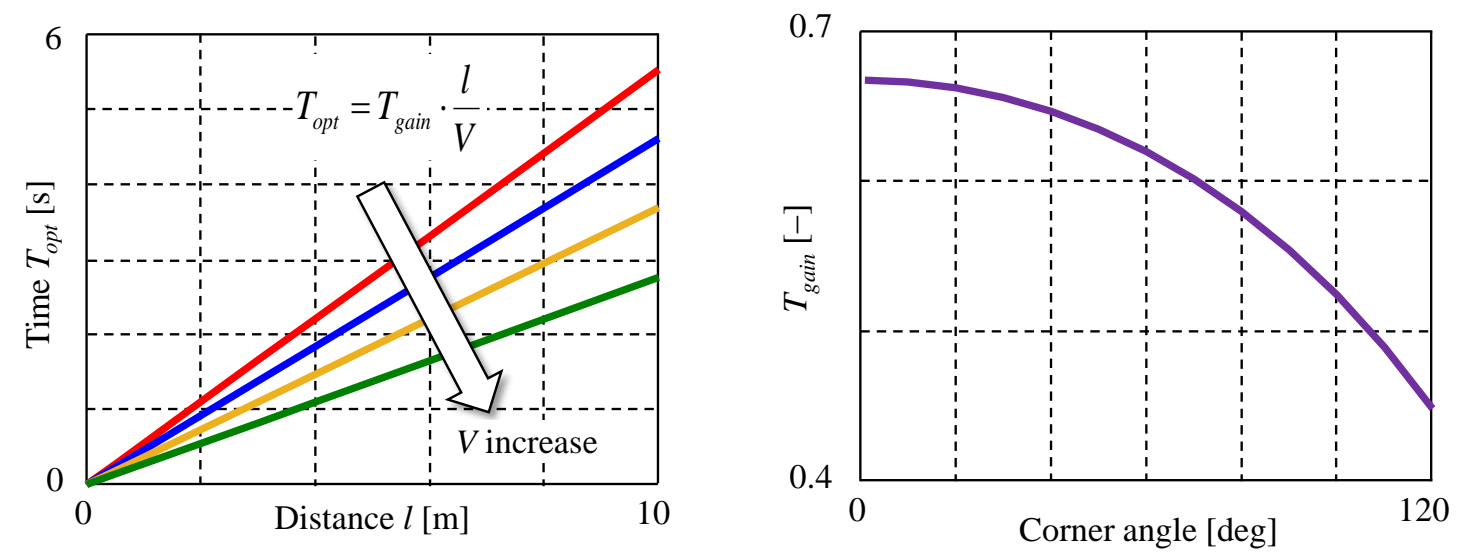

Fig. 3 The relationship between $l$ and $T_{\text {opt }}$ is linear, as shown on the left-hand side of figure 3 . The coefficient $T_{\text {gain }}$ of the formula shown in the figure represents the gradient of the graph, and it is a constant value that is determined by the angle of a corner; this variable is not affected by a vehicle's speed. Therefore, $T_{\text {opt }}$ is determined from road's configuration, and target yaw rate can be obtained.

つまり, 道路形状が決まると, 距離 $l$ を決めれば時間 $T_{\text {opt }}$ が一意に決まる. コ一ナの角度が 90 度以外の角度で あっても, 線形の関係があることは変わりない. そこで, 各角度における $T_{\text {gain }}$ の值をマップとして持っておけ ば，いかなる角度のコーナであってもクロソイド曲線上を走行するための目標ヨーレイトを決定することができ る. コーナの角度と $T_{\text {gain }}$ の関係を図 3 の右図に示寸.

\section{$2 \cdot 3$ 距離 $l$ の決定方法}

急操舵を防ぐために距離 $l$ は大きくとることが望まれる.しかし, 距離 $l$ が大きすぎると, 図 4 の左図の緑線 のようにコーナを曲がる際に道路から逸脱してしまう。そこで，道路の角からの距離 $\varepsilon$ と距離 $l$ の関係を調べる と，図 4 の右図の関係が得られた. $\varepsilon$ が負の值の領域は道路から逸脱してしまう領域を意味している.

つまり, 道路幅が決まれば, 道路の角からの距離 $\varepsilon$ を決めることで距離 $l$ は一意に決まることが分かる.ここ で, $\varepsilon$ は少なくとも車両幅よりは大きく設定する必要がある.
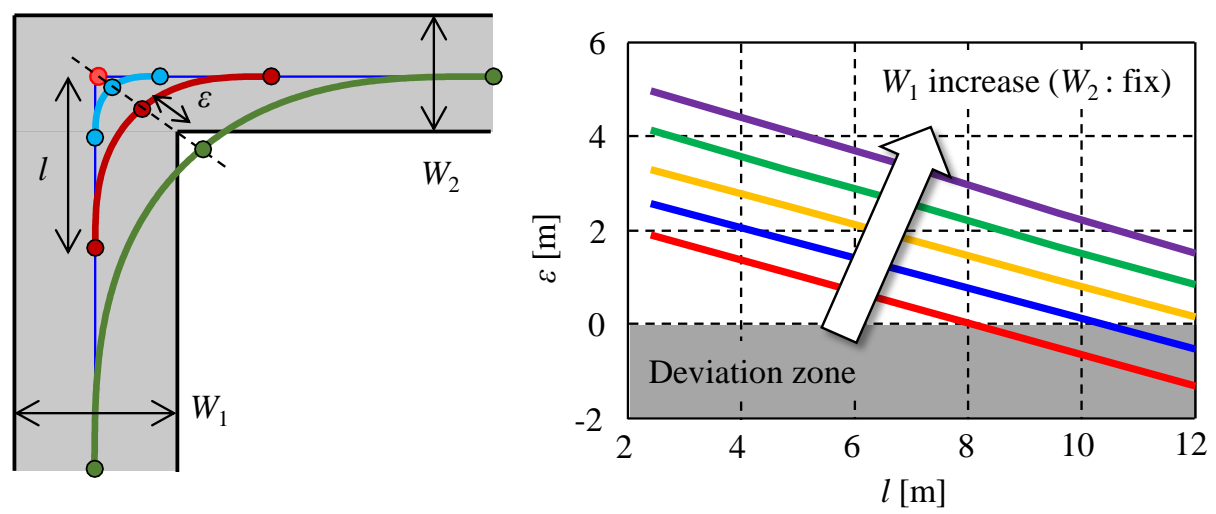

Fig. 4 When $l$ is too large, the vehicle deviates from the road. $\varepsilon$ is the shortest distance from corner of the road to the driving path. On the right-hand side of figure 4 shows the relationship between $l$ and $\varepsilon$. If $\varepsilon$ is negative value, then the vehicle will deviate from the driving path. So $\varepsilon$ must be set longer than the width of the vehicle. Then $l$ is determined by $\varepsilon$. 
以上から，目標ヨーレイトが決定されるまでの流れは以下の手順(1)〜4(4)ようになる.

(1)道路の角からの距離 $\varepsilon$ を設定する.

(2)図 4 の右図の関係から, クロソイド曲線が始まる点と次に目指寸ノードまでの距離 $l$ が一意に決まる.

(3)図 3 の左図の関係から, 時間 $T_{\text {opt }}$ が一意に決まる.

(4)目標ヨーレイト $\gamma^{*}(t)$ が決定される.

さらに, 本手法は低速を想定しているため車両の動特性を無視すると, 目標操舵角 $\delta^{*}$ は目標ヨーレイト $\gamma^{*}$ と車 両の定常ヨーレイトゲイン $G$ を用いて，式（4）で表される.

$$
\delta^{*}(t)=\frac{1}{G} \frac{\pi}{6 T_{o p t}} \Delta \Psi \sin \left(\frac{\pi}{3 T_{o p t}} t\right)
$$

ただし, 定常ヨーレイトゲインとは二輪モデルにおける車両のヨーレイトと操舵角の関係を表す值であり, 低 速時においては車速 $V$, 車両のホイールベース $L$, ギア比 $N$ を用いて式 (5) で表される．車速が増加した場合は スタビリティファクタを考慮して定常ゲインを求める(安部，2009).

$$
G=\frac{V}{N L}
$$

\section{3. 操舵角指令値生成手法}

式 (4) は時刻 $t$ に応じて目標操舵角 $\delta^{*}(t)$ が決定されるプログラム制御である. しかし，実際の市街地での走行 において, 障害物の回避やセンサの誤差等の外乱により一度目標経路から外れると, この目標操舵角では目標経 路に復帰することができない.

そこで本章では，時々刻々と得られる自車の位置・姿勢などの車両の状況に応じて操舵角を制御する手法につ いて示す．一般に操舵モデルとしては前方注視ドライバモデルが広く用いられている(藤岡, 2007). また, 古性 らは車両の前方注視点における目標コースからの誤差に応じて, 将来その目標地点に達するための目標ヨーレイ 卜を算出し，それを実現するように操舵している(古性他，2014)。これらの従来手法では目標コースからの誤差 として横偏差を用いるが，本手法ではドライバから見た注視点偏角をもとに操舵量を決定する．さらに，車両の 周りに半径の異なる同心円を二つ設け，その円周上に前方注視点をそれぞれ置く。このときの二つの注視点偏角 をそれぞれ $\varphi_{1}, \varphi_{2}$ とする. これらの関係図を図 5 に示す。

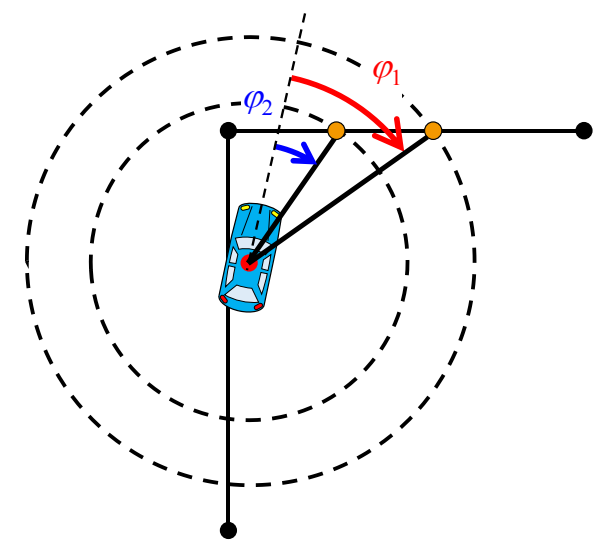

Fig. 5 In the proposed method, two concentric circles are placed around a vehicle onto which two gaze points are added. And two variables for the direction a vehicle is facing, $\varphi_{1}$ and $\varphi_{2}$, are prepared. They are obtained from the data of the vehicle's position. 
偏角 $\varphi_{1}, \varphi_{2}$ は自車の位置・姿勢情報から求められる. これらと二つのゲイン $a_{1}, a_{2}$ を用いて操舵角指令值は式 （6）を用いて算出する.

$$
\delta(t)=a_{1} \varphi_{1}(t)+a_{2} \varphi_{2}(t)
$$

以下に上式のゲイン $a_{1}, a_{2}$ の決定方法を示す. なお，これらは走行前にオフラインで求める.

まず，例として 90 度の右折を目標コースとし，そのコースを走行する時の目標操舵角 $\delta^{*}$ を式 (4) より算出す る.このときの目標操舵角 $\delta^{*}$ の時系列データを図 6 の左図に示す. 次に, その目標操舵角で走行した際の偏角 $\varphi_{1}$, $\varphi_{2}$ をシミュレーションにより算出する. このデータを図 6 の右図に示す. ここで，目標操舵角 $\delta$ *を式（6）の左 辺に， $\varphi_{1}, \varphi_{2}$ を右辺にそれぞれ代入すると，

$$
\delta^{*}(t)=a_{1} \varphi_{1}(t)+a_{2} \varphi_{2}(t)
$$

と表され，この式を満たすゲイン $a_{1} ， a_{2}$ を最小二乗法により求める.このようにして求めたゲイン $a_{1}, a_{2}$ を用い ることで，走行時に時々刻々と得られる自車の位置・姿勢情報から，走行経路がクロソイド曲線となるように操 舵角を制御することができる.
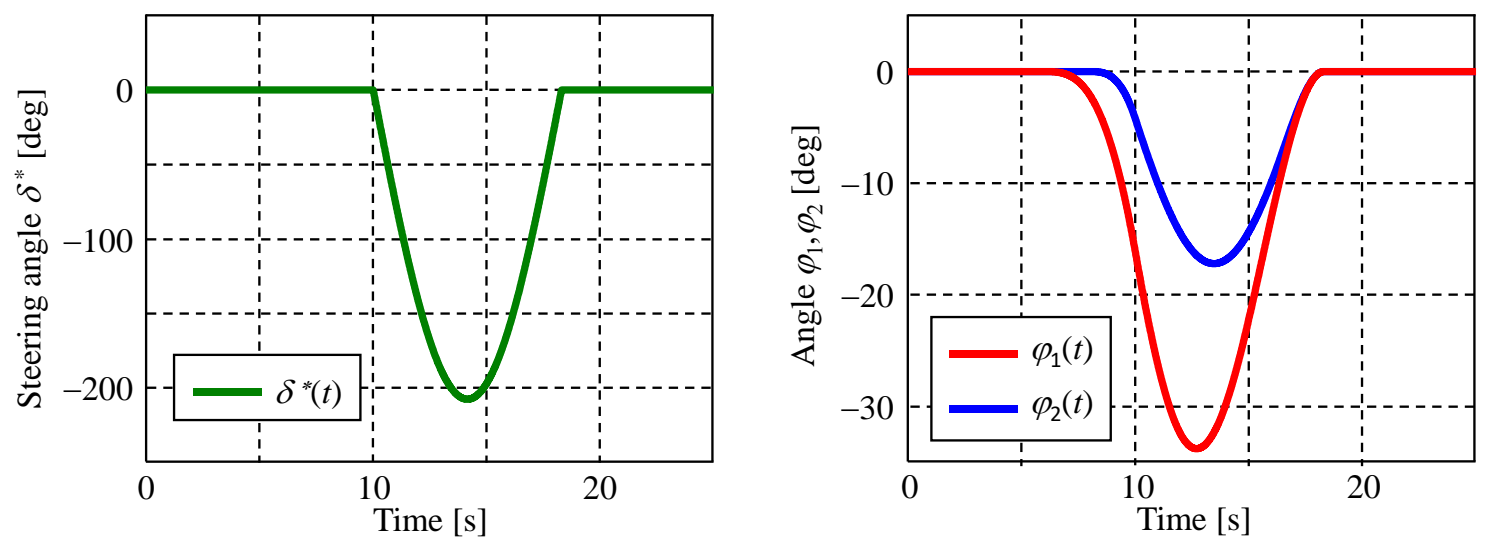

Fig. 6 The left-hand side of figure 6 shows the target steering angle $\delta^{*}(t)$, which is calculated using Eq. (4). The right-hand side, meanwhile, shows two angles, $\varphi_{1}(t)$ and $\varphi_{2}(t)$, which are described in figure 5 . When calculating the gain $a_{1}$ and $a_{2}$, the target steering angle $\delta^{*}(t)$ is substituted into the left-hand side of Eq. (6), and the angles $\varphi_{1}(t)$ and $\varphi_{2}(t)$ are substituted into the right-hand side of the same equation. Then, we calculate by using least squares method to satisfy Eq. (7).

\section{4. シミュレーション，実車実験}

3 章で求めたゲイン $a_{1}, a_{2}$ は 90 度のコーナを右折する際のデータを用いて算出したが, 図 7 に示すように前記 のゲイン $a_{1}, a_{2}$ はコーナ角度に依らずほぼ一定になる。つまり，一組のゲインを用いて他の角度のコーナも走行 できる. 本章では提案手法を用いたシミュレーションと実車実験の結果を示す.いずれも車速は一定とし, 90 度, 60 度, 120 度の計 3 つの右折コーナを有する走行コースを設定した.

図 8 の左図にシミュレーションの走行軌跡の結果を，また図 8 の右図にその時の目標操舵角を青色破線で，実 操舵角を赤色実線で示す。 なお, シミュレーション条件を表 1 に示す.

シミュレーションの結果より, 各コーナにおいて目標操舵角とほぼ一致する実操舵角が得られており, 目標コ 一スに対してオーバーシュートや定常偏差がないことが確認できる. 
またシミュレーションと同じ条件で実車実験を行った。実験車両は図 9 に示す小型電気自動車を使用してい る. 図 10 の左図に実車実験の走行軌跡の結果を，また図 10 の右図にその時の目標操舵角を青色破線で，実操舵 角を赤色実線で示す。実験結果より，実車においても各コーナにて目標操舵角にほぼ一致する結果が得られ，ま た走行軌跡もシミュレーションとほぼ同じとなり，提案手法の有効性を確認できた.

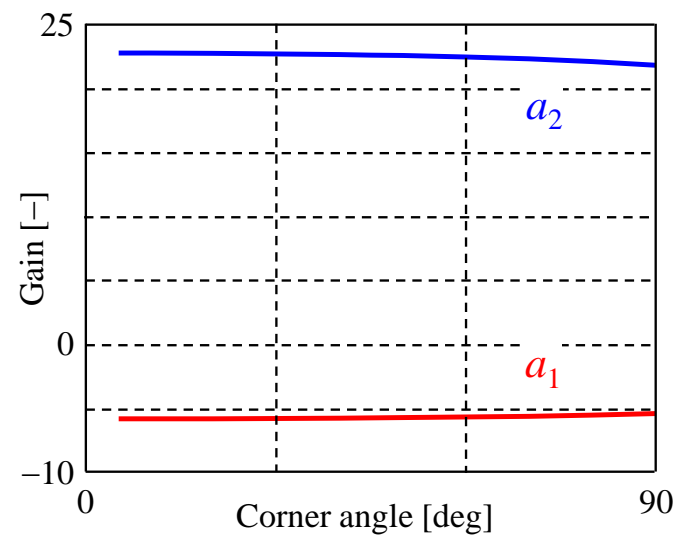

Fig. 7 Gains $a_{1}$ and $a_{2}$ are shown for each tested corner angle. The corner angle is in the range of $0-90^{\circ}$, and the value of the gain is almost the same. Thus, vehicle can generate the optimal steering angle with one set of gains $a_{1}$ and $a_{2}$.

Table 1 Simulation and experience conditions

\begin{tabular}{|c|c|}
\hline Vehicle speed $[\mathrm{m} / \mathrm{s}]$ & 2.0 \\
\hline Predictive distance $[\mathrm{m}]$ & $8.0,4.0$ \\
\hline Gain $a_{1}, a_{2}$ & $-5.37,21.84$ \\
\hline
\end{tabular}
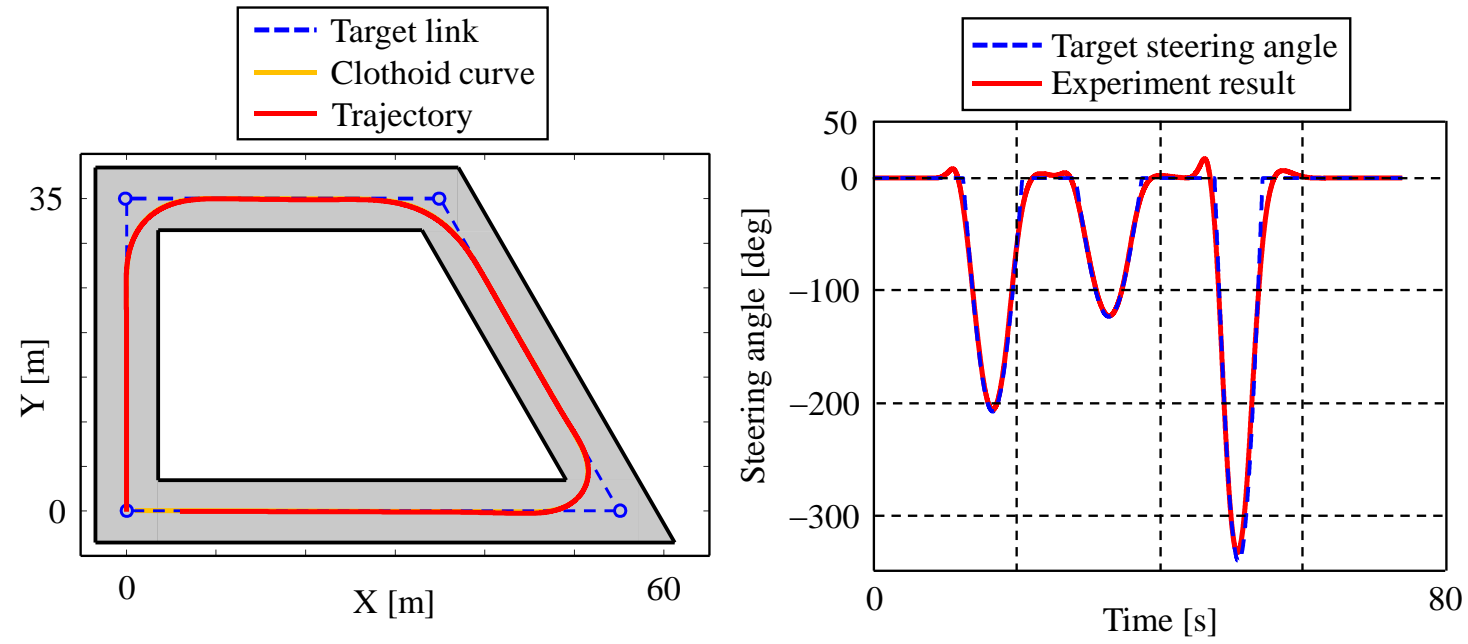

Fig. 8 The left-hand side of figure 8 shows the trajectory result of simulation, whereas the right-hand side shows the target steering angle as a blue dashed line and the simulation result as a red line. It is confirmed that the steering angle was mostly consistent with the target steering angle by control according to the vehicle's position, and there was neither an overshoot nor a steady-state error. 


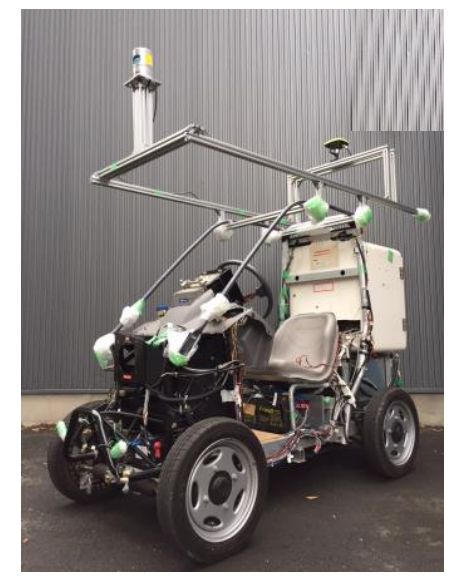

Fig. 9 An overview of the vehicle used in the experiment. It is an electric vehicle. It uses a global positioning system (JAVAD) and a laser range finder (Velodyne).
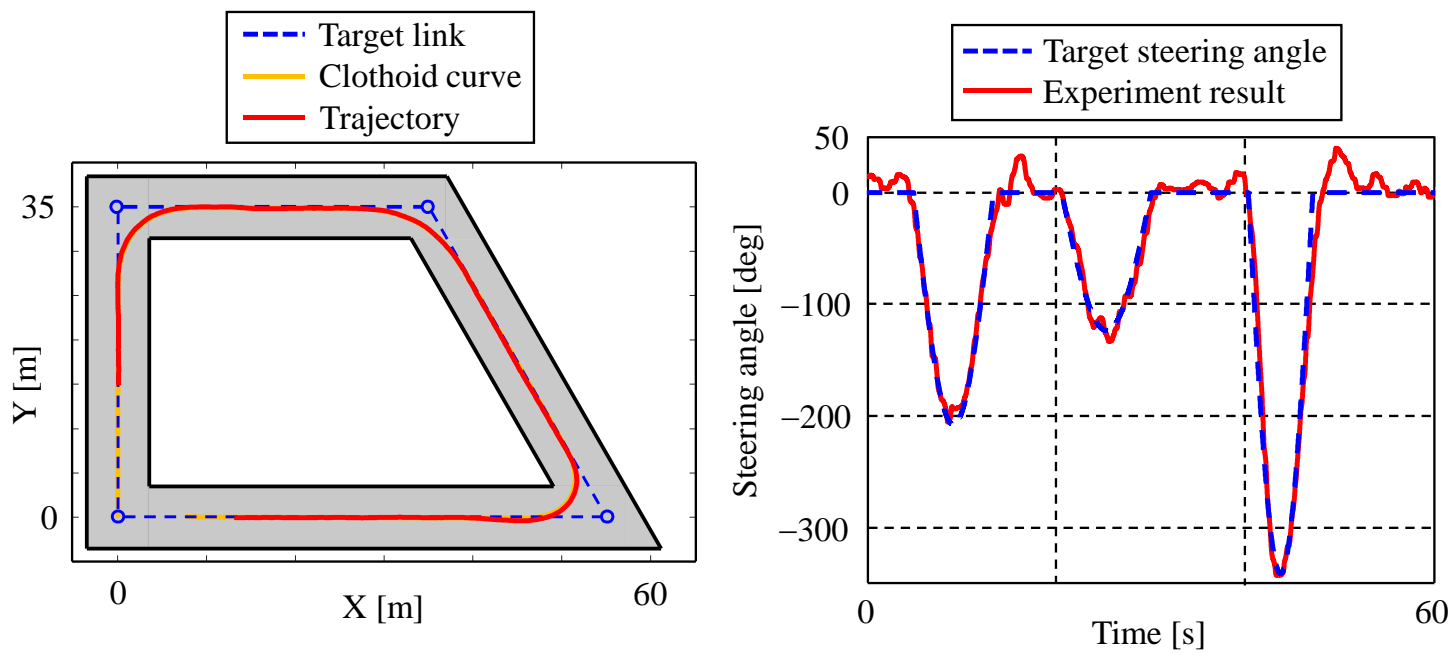

Fig. 10 The left-hand side of figure 10 shows the trajectory result of experiment, whereas the right-hand side shows the target steering angle as a blue dashed line and the experiment result as a red line. The experiment was performed under the same conditions as those in the simulation. It shows the validation of the proposal method in the real world.

\section{5. 考察（前方注視点をニ点にしたことによる効果）}

シミュレーションの結果から，本手法により各コーナにおいて目標操舵角とほぼ一致する実操舵角が得られて おり，コースに対してオーバーシュートや定常偏差がないことが確認できる. これは前方注視点を二点にしたこ とにより実現できたと考えられる.

前方注視点が一点の場合, 操舵角は注視点偏角 $\varphi_{1}$ とゲイン $a_{1}$ を用いて，式（8）で表される.

$$
\delta(t)=a_{1} \varphi_{1}(t)
$$

このとき, シミュレーションで得られた操舵角 $\delta(t)$ と注視点偏角 $\varphi_{1}(t)$ を用いて 3 章と同じ手法でゲイン $a_{1}$ を求 めると， 5.43 となる．一方で，前方注視点が二点の場合，ゲイン $a_{1}, a_{2}$ はそれぞれ負の值と正の值をとる. 
図 11 に前方注視点を一点として走行したシミュレーション結果を示す. ただし, 前方注視距離は 4 章の外側の 前方注視点と同様に $8.0 \mathrm{~m}$ とする. シミュレーションの結果より, 前方注視点が一点では切り始めが早くなるこ とで目標コースの内側を走行し, 目標に対して操舵量も不足し, また切り戻しも遅いため目標コースに対してオ ーバーシュートしていることが分かる.
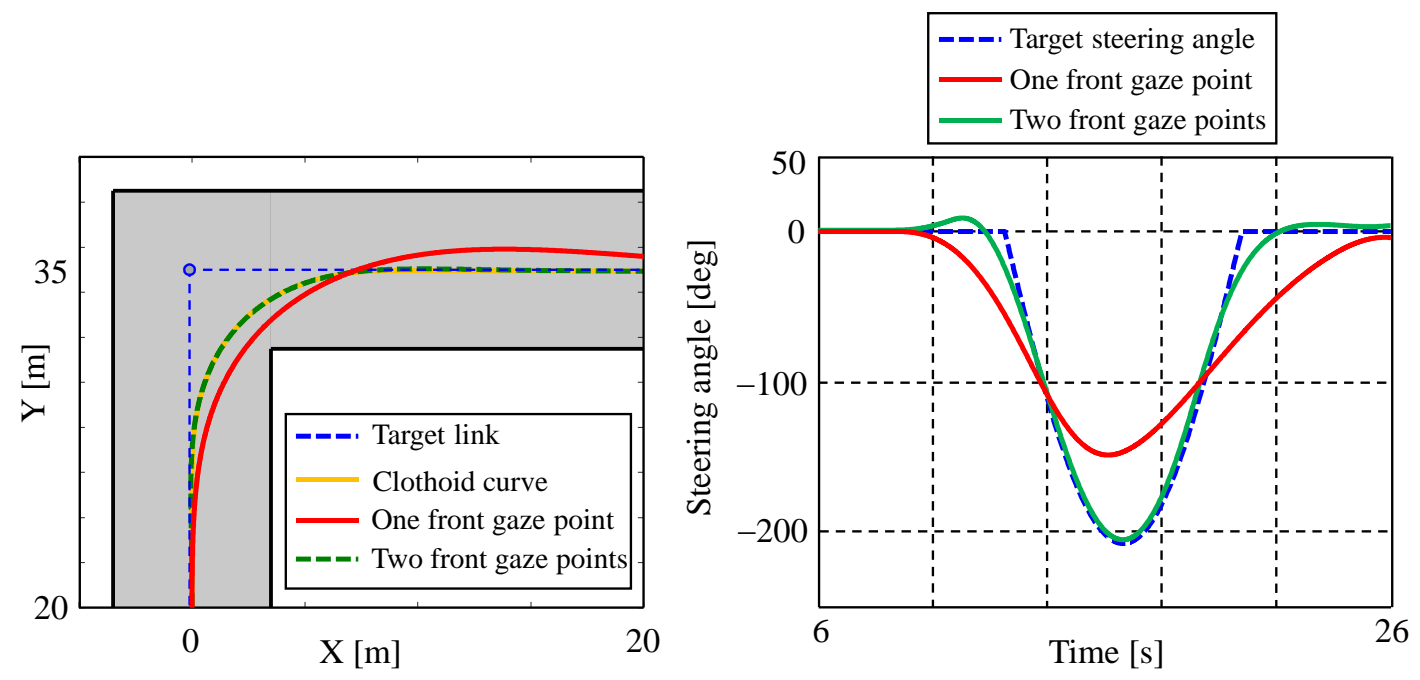

Fig. 11 Figure 11 shows the simulation result with only one front gaze point was used. The left-hand side of figure 11 shows the trajectory result of the simulation, whereas the right-hand side shows the target steering angle as a blue dashed line, the simulation result when one front gaze point was used as a red line and the simulation result when two front gaze points were used as a green line. There is both an overshoot and a shortcut; this is because the vehicle started turning too early and returning side in steering is gradual.

図 12 にそれぞれの仕様の注視点偏角とゲインの值を掛け合せたもの（赤線, 青線）と, 操舵角（緑線）を示す. この結果より，以下のことが分かる.

・前方注視点が一点 $\left(a_{1}: 5.43\right.$, 図 12 の左図 $)$

切り増し時の操舵角速度は大きく, 切り戻し時は小さくなる.

切り始めのタイミングが早く, また切り増しに対し，切り戻しに時間を要する.

・前方注視点が二点 $\left(a_{1}:-5.37, a_{2}: 21.84\right.$, 図 12 の右図 $)$

切り増しと切り戻しの操舵角速度が等しい.

負のゲインにより，切り始めのタイミングが後ろにシフトする.

切り増しと切り戻しに要する時間がほぼ等しい.

前方注視点が一点の場合, 切り始めのタイミングの早さや緩やかな切り戻しがオーバーシュートやショートカ ットの原因となると考えられる，前方注視時間を短くすればこれらを減らせられるが，その分手前を見て走行す ることになり，細かな修正操舵が多くなってしまう.

一方で二点のときは, 負のゲインの効果により切り増しと切り戻しに要する時間が等しくなるため, 従来の右 左折においてコーナ初期に操舵角, 操舵角速度が共に大きく発生する問題を解決できると考えられる. 

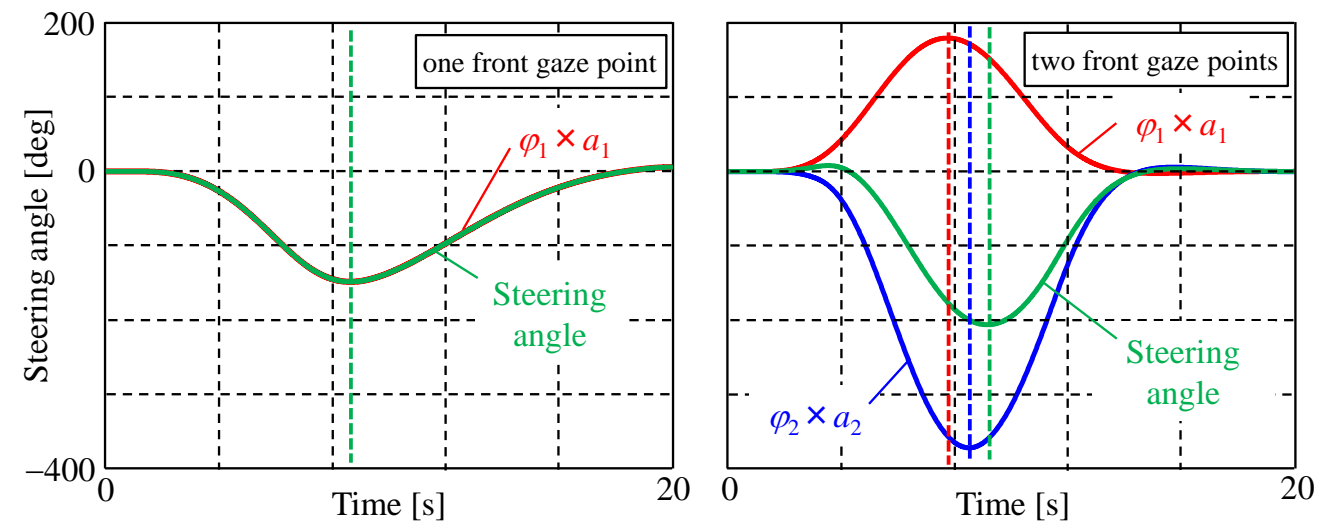

Fig. 12 Figure 12 shows the steering angle with one front gaze point (on the left-hand side) and two front gaze points (on the right-hand side). The red line represents the angle $\varphi_{1}$ multiplied by the gain $a_{1}$, the blue line represents the angle $\varphi_{2}$ multiplied by the gain $a_{2}$ and the green line represents the steering angle. It shows the time of increasing side in steering is shorter, and returning side in steering is longer when one front gaze point was used. On the other hand, the time of increasing side and returning side are almost equal when two front gaze points were used.

\section{6. 結}

本稿では，市街地での自動運転を想定し，道路のノードとリンクで構成される直線的な簡易地図情報と自車の 位置・姿勢情報を用いて，交差点の右左折をより滑らかな操舵で走行する手法を提案した．また，シミュレーシ ヨンと実車実験によって提案手法の有效性を検証した。本研究で得られた結果を以下にまとめる.

・道路構造や環境が複杂隹な市街地での走行を想定し，環境認識に依らず自車の位置・姿勢情報のみでも交差点 での右左折を走行できる操舵角の制御手法を提案した.

・道路のノードとリンクで構成される直線的な簡易地図情報を用いて, 走行経路の曲率の二階微分までの連続 性を保証し, ドライバの乗り心地が考慮された走行経路となるような目標操舵角を生成できた.

・自車の位置・姿勢情報に応じた操舵角の制御手法を示し, 最小二乗法により得られた一組のゲインを用いれ ば他の角度のコーナであっても走行できることをシミュレーションにより確認した.

・実車実験により, 走行経路にオーバーシュートやショートカット, 定常偏差がないことが確認できた. また, 前方注視点を二点設けることで第五章で述べたように操舵角速度が抑えられ，実操舵角が目標操舵角に滑ら かに追従しており, 提案手法の有効性を示した.

\section{文献}

安部正人，自動車の運動と制御，東京電機大学出版局(2009), pp.94-95.

藤岡健彦, 前方注視ドライバ・平面二輪自動車系の安定性に関する理論研究, 自動車技術会学術講演会前刷集,

No.11-07 (2007), pp.29-34.

古性裕之, 風間恵介, 孕石泰丈, 毛利宏, 複数の前方注視点を用いた車線追従制御測の提案一定常旋回中の

定常偏差除去と減衰比向上の検討一, 自動車技術会論文集, Vol.45, No.2 (2014), pp.315-321.

磯谷十蔵, 藤田嵕平, 林隆三，ポンサトーン・ラクシンチャラーンサク，永井正夫,

超小型電気自動車のインホイールモータと操舵制御を用いた前方障害物自動回避システムの開発, 自動車

技術会論文集，Vol.42, No.1 (2011), pp.87-93. 
Mouri, H., Satoh, S., Furusyo, H., and Nagai, M., Investigation of automatic path tracking using an extended Kalman filter, JSAE review, Vol.23, Issue 1 (2002), pp.61-67.

荻原瑛彦，松實良祐，林隆三，デジタル道路地図情報を用いた自動運転アルゴリズムに関する研究，日本機械学 会 2015 年度年次大会講演論文集(2015), “G1800302-1”-“G1800302-5”.

菅沼直樹，松井俊樹，自動運転自動車の走行経路高速生成法，自動車技術会論文集，Vol.42, No.6 (2011), pp.12811286.

魚住剛弘，菅沼直樹，GNSS/INS と白線検出の融合による自動運転自動車の自己位置推定，自動車技術会論文集， Vol.42, No.5 (2011), pp.1151-1156.

\section{References}

Abe, M., Automotive vehicle dynamics theory and application, Tokyo Denki University Press(2009), pp.94-95 (in Japanese). Fujioka, T., Theoretical research on the stability of the closed system composed of a look-ahead driver and a planer vehicle, Proceedings of Society of Automotive Engineers of Japan, No.11-07(2007), pp.29-34 (in Japanese).

Furusyo, H., Kazama, K., Haramiishi, Y. and Mouri, H., Investigation on the driver’s steering model employing several preveiw points : Zero steady state error during constant curvature cornering and arbitrary damping characteristics, Transactions of Society of Automotive Engineers of Japan, Vol.45, No.2 (2014), pp.315-321 (in Japanese).

Isogai, J., Fujita, S., Hayashi, R., Pongsathorn, R. and Nagai, M., Development of autonomous forward obstacle avoidance system by using in-wheel-motor and steering control of micro electric vehicle, Transactions of Society of Automotive Engineers of Japan, Vol.42, No.1 (2011), pp.87-93 (in Japanese).

Mouri, H., Satoh, S., Furusyo, H. and Nagai, M., Investigation of automatic path tracking using an extended Kalman filter, JSAE review, Vol.23, Issue 1(2002), pp.61-67.

Ogiwara, A., Matsumi, R. and Hayashi, R., Study on autonomous driving algorithm based on the digital road map, Mechanical Engineering Congress, Japan (2015), “G1800302-1”-“G1800302-5” (in Japanese).

Suganuma, N. and Matsui, T., Fast trajectory generation method for autonomous vehicle, Transactions of Society of Automotive Engineers of Japan, Vol.42, No.6 (2011), pp.1281-1286 (in Japanese).

Uozumi, T. and Suganuma, N., Localization method for autonomous vehicle by fusing GNSS/INS and lane marker detection, Transactions of Society of Automotive Engineers of Japan, Vol.42, No.5 (2011), pp.1151-1156 (in Japanese). 